\title{
Curriculum Development in the Teaching of Mathematical Proof at the Secondary Schools in Japan
}

\author{
Tatsuya Mizoguchi, Hideki Iwasaki, Susumu Kunimune, \\ Hiroaki Hamanaka, Takeshi Miyakawa, Yusuke Shinno, \\ Yuki Suginomoto and Koji Otaki
}

\section{Aim and Key Questions of the Workshop}

In the workshop, we aimed to share a theoretical framework as well as some issues on the teaching of mathematical proofs through Grades 7-12 of secondary schooling in Japan. The difficulties faced by students in learning mathematical proofs are well known. The key questions in the workshop were as follows: (1) What kind of teaching content should be included in the secondary curriculum for the teaching of mathematical proofs? (2) What kind of evolution should be envisioned in the course of the curriculum? (3) How can we allow comparing different curriculums for teaching mathematical proofs with different countries in terms of our proposed framework?

\section{Activities and Presentations During the Workshop}

We first introduced our research project and theoretical perspective. In this introduction, the first and second questions were considered. Participants were then divided into three small topic groups based on their interests. The contributors who took part in each of the topic groups, theoretical framework, what is a proof in Japan, and teaching materials, are shown in the following table. Through these activities we intended to discuss the third question with international participants.

T. Mizoguchi ( $\square)$

Tottori University, Tottori, Japan

e-mail: mizoguci@rs.tottori-u.ac.jp; tatsuya_ds@me.com

(C) The Author(s) 2017

G. Kaiser (ed.), Proceedings of the 13th International Congress on Mathematical

Education, ICME-13 Monographs, DOI 10.1007/978-3-319-62597-3_133 


\begin{tabular}{l|l}
\hline $\begin{array}{l}\text { Topic group } \\
\text { activities }\end{array}$ & Contributed team members and contents \\
\hline $\begin{array}{l}\text { Theoretical } \\
\text { framework }\end{array}$ & $\begin{array}{l}\text { T. Mizoguchi and Y. Shinno made a presentation about the framework } \\
\text { and gave examples from upper secondary school textbooks in Japan }\end{array}$ \\
\hline $\begin{array}{l}\text { What is proof in } \\
\text { Japan? }\end{array}$ & $\begin{array}{l}\text { T. Miyakawa and S. Kunimune explained what we call "proof" in Japan } \\
\text { by referring to geometrical proofs in lower secondary school textbooks }\end{array}$ \\
\hline $\begin{array}{l}\text { Teaching } \\
\text { materials }\end{array}$ & $\begin{array}{l}\text { H. Hamanaka introduced the mathematical proof related to } \\
\text { parallelograms. Y. Suginomoto, K. Otaki, and H. Iwasaki introduced the } \\
\text { operative proof related to Sylvester's theorem }\end{array}$ \\
\hline
\end{tabular}

After the group activities, we had an opportunity to engage participants in reporting the activity of each group. At the end of the workshop, Hideki Iwasaki made a closing remark about the importance for future research of sharing this research theme in mathematics education.

Open Access Except where otherwise noted, this chapter is licensed under a Creative Commons Attribution 4.0 International License. To view a copy of this license, visit http://creativecommons. org/licenses/by/4.0/.

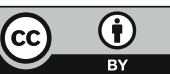

